\title{
Use of language games in advertising texts as a creative approach in advertising management
}

\author{
Aleksandr Teletov ${ }^{1}$, Svetlana Teletova ${ }^{2}$, Nataliia Letunovska ${ }^{1}$ \\ ${ }^{1}$ Department of Marketing and MIA, Sumy State University, Sumy, Ukraine \\ ${ }^{2}$ Department of Russian and World Literature, Sumy State Pedagogical University named after Makarenko, Sumy, Ukraine
}

\section{Article Info}

Received Jan 11, 2019

Keyword:
Advertising (Ad)
Advertising texts (Ad texts)
Commercial name
Brand
Language game
Slogan
Types of language game

\section{Corresponding Author:}

Nataliia Letunovska, Department of Marketing and MIA, Sumy State University

2 Rymskyi-Korsakov Street, Sumy, Ukraine, 40007

Email: n.letunovska@gmail.com

\begin{abstract}
The article analyzes the essence of language game, different approaches to the interpretation of this category, its potential for creating the effect of communicative influence on the consumer in the advertising text. Language game is seen as conscious violation of language norms, rules of linguistic behavior, distortions of language cliche in order to provide more expressive power to the text of an advertisement. Game strategies are implemented in three types of advertising such as advertising texts, slogans and advertising names. Authors use descriptive method, which includes observation, generalization, interpretation and classification of the test material, component analysis method. A totality of gaming techniques was found to help present an advertising product as attractive as possible. It is stated that virtually all levels of language have a significant potential for implementing the functions of the language game in the advertising text. Examples of various techniques of use of the phonetic and graphic game, methods of lexical and word-building games are revealed. The game potential of grammatical tools is shown. Particular attention is paid to the handling of case-law texts as one of the most widely used methods of speech game advertising. The combination of different types of speech games has become a common phenomenon for its implementation in advertising. It is concluded that the language game allows to realize the fundamental principle of creating a bright advertising message. Use of these tools reflects one of the main trends in modern advertising language which means installation of originality, creativity, and extraordinary.
\end{abstract}

\section{Introduction}

Advertising has become the main link between consumer and production. It is increasingly entering into the life of a modern person, accompanying traveling, working on a computer, using media, different services and so on [1]. Modern advertising messages are so large that standard images and texts are no longer received by the recipient. The diversity of advertising is motivated extra linguistic, and above all the laws of marketing communications. The main task of advertising is not only to convey information about the product, its properties, but also to encourage the consumer to try the new product and promote its re-use, stimulate the sale of goods, form or develop a commitment to a particular brand, etc. The effectiveness of advertising appeals is primarily due to some or other innovative approaches to their creation, aimed at suggesting new 
emotional images to a person [2]. To do this, advertising texts use certain marketing, design, linguistic techniques. One of the most effective among the latter is a linguistic game. It is an effective and expressive way that makes any ad text original, increases its expressiveness, emotional charge, promotes informal contact with the consumer, etc. Widespread use of gaming techniques has become a vivid sign of modern advertising. The reflection in the linguistic game both linguistic and extra-linguistic problems beyond the limits of linguistic reality deepens the interest of specialists in the study of this phenomenon in general and in advertising in particular. This determines the need for multi-dimensional study of the language game and the peculiarities of its implementation in the advertising discourse. Particularly relevant is the pragmatic aspect of the study of this phenomenon, which involves an analysis of its functional potential in advertising texts. A number of studies have been carried out on modern advertising activities, language of advertising and creative techniques used in advertising messages. In the works of scientists and well-known managers [3-5] current issues of modern management, branding are considered. Authors of [6-8] analyze advertising from the point of view of marketing. Authors of [9-14] study the language of advertising, the features of advertising texts, their structure, the use of various means of influence on the consumer audience, etc. Game techniques in advertising are explored in [15-18] and others. The phenomenon of language game was the subject of the attention of scientists only at the end of the 20th century, which was probably due to the fact that the language game went beyond fiction and spoken communication and was widely used in advertising and mass media. It became an integral part of the active processes taking place in the modern language. The language game is considered in various aspects: communicative, cultural, and linguistic. The multifaceted approach to the study of this phenomenon is due to the special influence of communicative technologies with their rich arsenal of verbal means on the recipient of advertising information. Although recent works have been published and they summarize the results of many years of research on language play, but the analysis of these publications allows us to conclude that today's game techniques are well-studied on the basis of conversational communication, fiction, media, but language game is not sufficiently investigated in the sphere of advertising. The purpose of the article is to study the peculiarities of the implementation of gaming techniques in advertising texts of various types, and analysis of the functions of language game, which facilitate its widespread use in modern advertising.

\section{Material and methods}

The research was conducted on the basis of Ukrainian-language and Russian-language advertising, which functions in the advertising space of Ukraine. Features of the implementation of gaming strategies are considered in three types of advertising: advertising texts, slogans and advertising names (brands). The research methods reflect their general purpose and objectives. The study uses traditional methods: a descriptive method, which includes observation, generalization, interpretation and classification of the test material and enables to characterize the linguistic facts under consideration; component analysis method.

\section{Results and discussion}

The perception of product by potential consumers is significantly influenced by the language of advertising. Therefore, an important factor in the success of an advertising campaign is the competent use of language structures. With the help of promotional text, an image of a product or service is formed which may attract the attention of a potential consumer. One of the most effective means of communicative influence in a promotional message is a language game. The term "language game" does not have a single interpretation. The lack of a common definition makes it possible to understand and explore the various aspects of this phenomenon more deeply. The concept of language game was introduced by the Austrian philosopher L. Vittgenstein [19]. He believed that the interaction of language and life is formalized in the form of language games based on certain social regulations. From his point of view, the language game is a form of life itself, reality that we perceive through the prism of language. In linguistic scientific literature, there are different approaches to the definition of language game. Moreover, besides the specified term, other terms are used, such as "game of words", "pun", etc. The content of these concepts is also dissimilar in different authors. O.S. Ahmanova [20] using the term "game of words" practically identifies it with a pun, which is understood as "a type of speech, consisting of humorous, irony of using different meanings of the same word or two words that sound approximately the same".

Gradually, scientists began to expand the boundaries of this concept. In the broad sense of the term, the language game is interpreted as a special deviation from the linguistic norms to create an aesthetic effect. In this approach, the language game includes all cases of non-standard, creative use of linguistic units. T.V. 
Matveeva [21] considers the language game as a speech behavior with the installation to achieve additional effects of influence, usually for the purpose of entertainment, fun, rest. The language game, in the author's opinion, is carried out by the context-based transformation of the linguistic means and their removal beyond from ordinary application. The widest possible understanding of the term "language game" is found in [18]. The author emphasizes that language game is an unconventional, non-canonical use of the language; it is creativity in the language, an orientation to the hidden aesthetic possibilities of the linguistic sign.

In our study, we use such working definition: "the linguistic game is a stylistic method, consisting of a conscious violation of linguistic norms, rules of linguistic behavior, distortion of language cliche in order to provide a greater expressive force of the text". An analysis of the use of this phenomenon allows us to talk about a wide range of expressive possibilities of speech techniques, in particular in the advertising discourse. Language game is actively used as one of the ways of communicative influence on the mass recipient in the sphere of advertising. Language game performs various functions in advertising: it focuses on an advertisement, gives positive emotions to the perception of the text and helps to better remember it, adds an element of confusing the content of the advertisement and reduces the probability of its critique.

We investigate the peculiarities of the implementation of game strategies in the three types of advertising texts such as advertising texts, slogans and advertising names (brands). Advertising products are primarily advertising text that demonstrates the benefits of the product, slogan of the enterprise which the person heard (simply reading the slogan is not effective), and the brand that creates the consumer's perception. The use of these advertising tools is based on the assumption that the potential consumer will remember the brandsupported slogan and understand the benefits of this company's products. If necessary he will definitely buy it. Consequently, the result of advertising is: 1) advertising texts (advertising); 2) micro text (slogans); 3) names (brands). Slogans and names can function as independent verbal means with their special tasks, and as auto semantic components of large texts [22]. Most representatives of enterprise management build marketing in such a way as to bring their name to consumers, to ensure the presence of their advertising and to guarantee the recognition of their brand. The language game can be used in various types of advertising: in print, where the advertisement is implemented only in writing; external, where the consumer can also observe the graphic form of the text; in a radio advertisement that provides an opportunity to hear the sound form of a word or phrase that is played out and to correlate it with the content of an advertisement; in television advertising, which creates conditions for audio-visual perception of information; in Internet advertising that combines all of these features. The most effective carrier for advertising and further sale of certain goods 20-30 years ago were printed media of advertising information. But today, printed promotional products, as well as newspapers, magazines and some types of external media, no longer attract the buyer. The only exception is the Internet, the share of verbal submission of which has recently been steadily increasing. Today, small text ads, such as Google sites, work much better, because they are contextually adequate and displayed only to those who may be interested and needed. Such advertisements refer to contextual advertising that is oriented on the content of the web page and placed in accordance with the subject matter of the materials. Contextual advertising is selective and aimed at the visitors of the Internet site, whose sphere of interests is potentially intersect with the subject of the product or service being advertised. In addition, such advertisements are more likely to be demonstrated to consumers who use the Internet to find information about products and services, as the keyword principle is used to determine the relevance of the promotional material. Recently, contextual advertising has significantly pushed the banner, which is tricky trying to get into the life of the consumer (viewer, listener, reader, etc.), regardless of whether he is interested in this advertising message or not [23]. Copywriters use various linguistic and psychological techniques. The main task of any advertising text is to raise the interest of the potential consumer in the advertised products. Verbal (linguistic) and non-verbal (visual, graphic, etc.) means of influence on the consumer are used in advertising. Almost all levels of language have a significant potential for implementing gaming techniques in promotional texts. Gaming models can be related both to the form and to the content of the linguistic units. According to [17] such types of speech games are distinguished: phonetic, graphic, word-formation, morphological, game with precedent phenomena, processing of ambiguity. Our research showed that this classification can be supplemented. The main types of speech game we consider it expedient to submit as follows. The phonetic game helps to convey the sound form of the word or phrases that are played to the recipient, and is realized primarily through sound repetitions (assonance, alliteration, paronymatic attraction): Тыщщщщи сувениров (the name of the network of trademark Cactus). The phonetic game can be based on anaphora (repeating the first syllables of words): Щоразу що треба (marketing place Rozetka) or epiphora (repeating the last syllables): Зимова країна на 
ВДНГ. Святкові традииї живуть туть; Вітамін - ЦЕ: пив-ЦЕ, вин-ЦЕ, саль-ЦЕ, м'яс-ЦЕ, ковбаси $\kappa i л ь-Ц E$. Using the hyphen in the last example graphically supports the epiphora and emphasizes the conscious targeting of the language game. Attracting the attention of the recipient contributes to the copying of spoken language: Щасспою (the name of the karaoke studio), as well as onomatopoeia of a certain manner of pronunciation: Бережи жуби ж детиштва - in the advertising of the dental firm the parable of the speech of a person without teeth that did not monitor his health; Стой. Црулна. Стрижом, брэим, пэрвы зорm! - Caucasian accent is imitated, because Caucasians are considered wonderful hairdressers. As can be seen from the examples, the phonetic language game, which is based on distortion of speech, is always combined with the violation of spelling rules. It should be noted that the imitation of the pronunciation must be in harmony with the content plan of the advertisement, otherwise it can cause the recipient1s irritation and, as a result, disregard advertising information. In advertising texts you can also find out the sounds of animals, birds or insects: Вусаті експерти обир-р-рають “Люкс" (dog food advertising); Жжук. Магазин гаджжетів (doubled is used not only in the name of the network of supermarkets and stores of electronics Zhuk, but also in the word "гаджетu", which amplifies the sound effect and attracts the attention of consumers). We associate the phonetic game with such an effective technique as rhyme: Let it snow, Let it snow, $4 G$ прийшов (Vodafone); МК "М'ясний" - ие вибір мій (advertising of the meat processing plant); 3 грипом годі жартувати, треба "Аміксин” приймати; "Карсил" - надає печінці сил (advertising of medicines); Не лінуйтесь - пререкредитуйтесь (advertising of the bank). Rhyming is the most common among phonetic game techniques, although in general examples of promotional texts based on the implementation of phonetic games, it is not widely used in advertising texts. They occur rarely, but they are quite an expressive means of attracting attention. Much more used the elements of the graphics game. In the interpretation of the graphic game there are two approaches: wide and narrow. In our study, we hold on to a broad approach, in which, under a graphical game, manipulation of all possible means of graphics, which includes lower and upper case letters (AлфaBim (the name of the vitamins, two parts of which are presented in advertising in different colors); Latin (Bukovel, Cepue Kapnam (the name of the Ukrainian mountain ski resort Bukovel is given in Latin); У Comfy good, смартфони тут (Comfy), Пылесос иSKAT искать WWW магазине SKAT.RU), mathematical and other signs $(+,-, \$, \&$, \#, etc.) (\#Чисто молочний (advertising of products of the trademark Galychyna), receptions of contraction of the words (Чем меньше в рекламе текста, тем лу \#Чисто поржать), font allocation, indent, underline, strikethrough, inverted letters, accents and so on. Graphic game can provide: the name of the product or the company, which creates the possibility of double reading (Ідеаль Немолоко (the name of the vegetable drinks of brand Nemoloko can also be read as Ідеальне молоко); SENSачія, на яку ви чекали (advertising of computers of the brand SENS), СТОМАТОЛОГіЯ (the name of the dental clinic consists of two words - “стоматолог” i “ $я$ ")); keywords in the text, which creates dual text (with two promotional messages), where a graphically highlighted short message is first read, made from fragments that are included in another longer message (МИ пропонуємо те, щзо БУДУСМО). Sometimes spelling mistakes are deliberately allowed in an advertisement, which allows you to add additional shades to the text of the advertisement or attract the attention of the recipients (Зимова країна на ВДНГ. Святкові традииії живуть туть). A word-of-mouth game involves different ways of creating neologisms (new words or statements, as well as new meanings of old words), occasional (individual author's tumors, used in conditions of a certain context) and potential words: Нова Активіа подбає про тебе суперзлаково! (Activia); Ціни - просто закупись (Eldorado); ВініПундіЯ. 3 нами весело! (the name of the store with children's goods); Пепсизм-коланизм (from the name of Pepsi-cola); - Мені соплевитирин, протизастудин, антивірусин, на-роботу-не-ходин. - А мені просто "Ергоферон”, as well as a game with the internal form of the word: чебупели (the name of the product, which combines two words “чебуреки" and "пельмені")); м'ясняики (sausages, which children love); Помогиня (name of the means for care of cleanliness). As can be seen from the examples, occasional innovations encountered in promotional messages are more often created by models of the noun, less often by verbs or adverbs. A word-of-mouth game can be combined with other game techniques, in particular graphic or phonetic, for example: БІБАБО (this occasional name of the cafe is created by reducing the three words - "більярд", "бар", "боулінг", which, moreover, begin with the same letter that adds sound effect). Quite often, advertisers also turn to lexical game. According to [21] the semantic provision of a language game is created by the atypical context of a playable unit, and in this area the language game is included in the broader phenomenon of contextsemantic transformations, losing its certainty. At the lexical level, the language game is represented by a game with polysemicity, homonymy and related phenomena (homoforms, homographs, homophones), paronyms, antonyms, lexical repetitions, etc. The lexical game in the ad text is mainly related to playing an ambiguity 
(giving it at least two or more interpretation options through the use of multivalued words, homonyms, etc.), for example: ВРЕМЯ ЕСТЬ (interpretation of the name of a cafe may have several options: nopa ecmb, ecmb время - поешь, etc.); Умно жить - умножить (ommones are played in the advertising of bank); Зв'язок без браку (advertising of the mobile operator); Сын за отия не автоответчик. In the latter example, the language game is achieved through the verbal phonosemantic convergence of words. The lexical game can include the use of polysemic words, which simultaneously realize two values. It results in both direct and figurative value of words in the human mind, for example: Людина складається на 70\% з води. Фільтрусш? Here the verb "фільтруєш" has two meanings - "you use a filter" and "think". Rarely, advertisements use game techniques when there is a transition from one word value to another within a single small segment of a message, for example: Плодіть та розмножуйте (advertising of copiers); Піднімаємо все! Hавіть настрій (advertising of forklift trucks). Antithesis is quite common in advertising texts (a stylistic method of enhancing the expressiveness of a statement due to a contrast of concepts or images, for example: КИСЛОмолочні йогурти СОЛОДКІ. The analysis of advertising texts showed that the most common means of the lexical language game is a lexical repetition of the speech element, which emphasizes the significance and enhances the emotional influence of the ad text: Відчуй норму - відчуй звільнення (advertising of the drug "Normolact"); Для найменших! Формула не проста, а ідеально проста (ECObaby brand name advertisement); Дякувати - не передякувати (trademark Torchyn); Грають вони - виграєте ви (Pari Match); Потрібні люди в потрібному місиі (advertising of site robota.иа); Маленькі сердечка для великих сердець (the advertising of tablets "Cardiomagnol" in the form of hearts). The morphological game consists in the use of non-standard grammatical forms of words that sometimes even violate the morphological norms: Кул прайз на любий сюрпрайз (Comfy) - the non-normative form of the pronoun "любий" is used instead of "будь-який”; Самий майонезний майонез - occasional form of higher degree of relative adjective is used. Morphological game in advertising is not as popular as graphic or word-formation. The broad potential of attracting the attention of potential consumers is played by precedent phenomena game, which is the introduction of a well-known expression in the advertising text, as a rule, in a transformed form (for example, the advertising of glasses using the poem by Pushkin "Autumn": Унылая пора - ОЧКОВ очарованье). Advertising appeals can be based on various precedent texts (winged words of great people (famous philosophers, scholars, writers, politicians, actors, athletes, managers, representatives of show business), proverbs, sayings, phraseologisms or their author's interpretations: Від інновації не втечеш - an advertising message built on a pretentious statement "Від долі не втечеш". An appropriate pun, a witty rethinking of the text, a well inserted quote from an artistic work introduces the stylistic diversity into the text of the advertisement, makes it "more alive", exacerbates the expressed opinion. For instance, in advertising of antifungal medicines Нам не страмен, ты, грибок! it is used the changed form which is known to all from childhood - the words from the fairy tale "Three pigs" (Нам не страмен серый волк) or На старт! Увага! Фари! instead of taking on races in athletics Ha cmapm! Увага! Мари! The use of language games can sometimes result in not the effect that advertiser or communicator has expected. In pursuit of creativity, some advertisers do not accurately predict the end result of the impact of advertising text on a potential consumer: involving the reader or viewer in a language game, they do not take into account the differences in the background knowledge of addressee and addresser, overstate the level of language competence of recipients of advertising information. The attempt to make the advertising text original often unfortunately causes a deviation from all sorts of norms (linguistic, communicative, ethical, legal, etc.). In the case that the language game is incomprehensible to the recipient or it appears to him to be inappropriate, such that violates certain norms advertising may turn out to be a communicative failure and cause a negative reaction of potential consumer instead of positive [17]. That is why some researchers believe that it is necessary to legally restrict the use of a number of linguistic techniques, in particular those that give the advertising text ambiguity. Published in [11] results of the survey of recipients indicate that approximately half of them believe that advertising texts with a language game are permissible from the point of view of social morality, and about one third believes that the play of ambiguity in advertising texts does not affect the younger generation negatively. But among people with philological training these results are $25 \%$ lower. Language game models are often a means of expressing a slogan. It is an effective sentence, statement or motto that reflects the essence of a commercial proposal, the unique quality of the product, the direction of the company, company in direct, foreign language or abstract form [2]. A purely linguistic definition of the slogan, which is felled as the minimum dedicative unit of advertising, is a key, semantic component of not one text but an entire advertising campaign. The slogan is an important part of the corporate style, which adds to the integrity of a number of promotional activities. This auto-semantic expression is often used as the only linguistic element of a poster (a 
text with a visual dominant). Together with the logo (from ancient Greek $\lambda \dot{o} \gamma o \varsigma$ - "word" $+\tau y \pi o \varsigma-$ "imprint"), slogan performs an important marketing function of identifying product and company. What is also important is the so-called positioning of a slogan (the achievement of the fact that a product, a service, an object being advertised could be distinguished from others). In [24] it is emphasized that advertising slogan performs a triple function: attraction of attention, primary informing and persuasion. In addition to these functions, slogan in advertising text performs other functions, including attraction, incentive, economic, image, and didactic. Slogan can promise to the reader or listener any benefit: Вікна нового покоління й свіже повітря у дарунок. To enhance the effectiveness of slogan it is important that it be relayed through the means of advertising, the media, through readers, listeners, viewers, than would help to find new supporters, and then followers of the appropriate consumer behavior [25]. The language layout of slogan is conditioned by the requirements of brevity, expressiveness, which in aggregate provides its aphoristic, precise, emotional charge. The short slogans are more expressive and attract more attention, for example, in the advertisement of motor oil "Perfekt": У сериі твоєї машини, long - commercially more profitable, because they contain more specific information that works more efficiently than generalized: М'якість бавовни та свіжість квітів у кожному «Lеnоr». The text of slogan should be designed for the unwitting attention of the reader or listener. In advertising messages, according to research, "the average headline is read five times more often than the texts themselves" [2]. The same can be said about slogans, which are the central component of any advertising message. They are more likely to be repeated and better remembered, since they represent key statements reflecting the company's position. Slogan should be vivid, visible and imaginative, which will ensure its rapid assimilation at the subconscious level. This will be facilitated by a change in communication expectations (the so-called "planned accident"), and a direct appeal to the reader, listener, viewer, and the motivating nature of the text of slogan, that is, the formation in the addressee of a system of guidance, aspirations and internal imperatives that motivate the person to act, etc. Language tools used in slogans are based on the categories of pragmatics - the choice of linguistic means as a result of their evaluation, their compliance with a particular marketing situation. Slogans use the following linguistic means: epithets (Ідеальна техніка для реального життя (Samsung), Новітні технологіï (Hitachi)), metaphors (Радість у вашому домі home (Rowenta)), hyperbole (Indezit. Прослужить довго), antithesis (Зв'язок з близькими на далеких відстанях (Ukrtelecom), Діє зсередини, результат - зовні (Activia)), rhyming (Гаджет на будь-який баджет (Comfi). Somewhat less common are deviations from normative spelling, the combination of Latin with Cyrillic, the use of occasional words, absent in the language system, etc. Not the most important place in the structure of the slogans occupy the structures of expressive syntax, in particular the clichés and motivational sentences (Прагни кращого! (Life), Увімкни Philips. Почни заощаджувати) [23]. The following suggestions will help to create a slogan and manage its effectiveness: 1) it is desirable that slogan, without losing its emotional orientation, indents the product or service or the company, the firm, the enterprise that produces them; 2) it is necessary to find the opportunity to inform their supporters that company should offer a new creative idea about products, services, projects, etc.; 3) directly emphasize those new characteristics of a product or service that will distinguish them favorably from goods or services-analogues; 4) to offer potential consumers a bright legend (dream) that will be needed to convey the idea to the widest possible audience; 5) apply the appropriate means of speech impact on the recipient, select the medium by which the slogan will most effectively and as quickly as possible reach as many potential consumers as possible. A successful slogan should be remembered and consolidate the association with the brand. One of the important tasks of marketing communications is to create a favorable image of the firm. A vivid image means is the brand name, which is the basis for the company's brand creation [6]. The classic of marketing philosophy F. Kotler characterizes brand as any name, trademark, containing certain content and relevant associations. The text component of brand is its name. Such names are onomi-microtebs with the naming purpose-setting (онім (from the Greek óvо $\mu \alpha$ - "name") - a word, phrase or sentence that serves to allocate the named object among other objects, its individualization and identification). These are the names of trademarks, companies, which main function is identification of the product / company. Creating names as a direction of communication creativity is called naming. The commercial name must satisfy certain criteria: marketing (conformity of the name of commodity), phonostylistic (euphony and memory), lingvo-cultural (conformity to associations, estimated connotations) and legal (conformity with the normative-legislative base) [22]. J. Gregory, CEO and founder of CoreBrand Corporation, emphasizes that brands are mental constructions that can best be described as the sum of all human experience, their semantic perception of ideas, and that exist in the form of consciousness or specific people or society [4]. According to experts, semantic space is "the $5^{\text {th }}$ space in which a person lives" [5]. Consequently, the semantic perception of brand is a concentrated idea of 
product, company that produces it, objective and subjective benefits, benefits of its purchase, etc. D. D'Alessandro, who served as executive director of the financial corporation, John Hancock Financial, from 1984 to 2004, eloquently describes brand as anything that comes to the head of a product about a person when he sees his logo or hears its name [3]. F. Kotler distinguishes six features that are characteristic of brand: quality (brand must be associated with a certain quality of a product), benefits (buyers when buying a product seek to obtain certain benefits provided by proposed brand), value (each brand carries value information for its consumer ), individuality (brand must express individuality of consumer), culture (brand is the embodiment of a certain culture), consumer (brand corresponds to a certain type of consumer) [26]. All the above makes it possible to understand brand as an object of the linguistic game, one of the most used forms of which is foreign language. And if for slogans, foreign language becomes a kind of installation on the extraordinary and guarantee of attraction of attention (for example, the advertising slogan of the car Seat Leon in the car center "Artex" during crisis on the territory of Ukraine sounds like Chihaly mi na crisis! or the slogan of the trade center "Media Market": Приходи за техникой - уезжай на автомобиле!). Name of brand in foreign language changes our understanding of a product. For the most part, English is used here, German, and rarely French, but there are cases of use of other languages. The use of Latin in the presentation of consumer must be associated with quality, high technical level of a product, fashion on it, etc. For example, this technique is used in the names of restaurants, beauty salons and women's underwear stores "Шерше ля фам", dating agencies and cafes "Tem-a-mem", etc. When creating an ad name, an effective method can be used when only part of the name is represented by a foreign language element, for example: РЫБА'LOVЕ, БИР ПИВО. There may be a non-standard implementation of the graphic game: staruŭ (association with the English word "star"), oбmin, etc. Unfortunately, not always the original ad name meets the requirements for commercial names. For example, the brand name of the Russian firm of shoes "Стелька Разин" cannot be considered successful. Russian Cossack Стенька Разін, the ataman of the uprising in Russia in the seventeenth century, is a symbol of cravings, courage, and freedom of love. Streets, squares are called by his name. It is clear that the name that is distorted in this way is not quite suitable for branding of footwear insoles. The same can be said about the commercial name of TАЗПРОМ, which is in line with one of the most famous Russian brands of ГАЗПРОМ, although it seems rather provocative for producers of basins.

\section{Conclusions}

The investigated features of the operation in the advertisement of the language game show that it has become an integral part of modern advertising messages. The game strategies used in advertising appearances are varied. There are such language games in ad sphere: graphic, word-building, precedent texts (together they make up about three quarters of advertising), phonetic, lexical, and morphological. The combination of different types of language games has become a common phenomenon for their implementation in advertising. It is confirmed that the language game is multifunctional. It's most important functions in contemporary advertising texts are attraction of attention, compression of meaning, modelling of certain emotions, expression of appreciation, etc. It is shown that with the help of the language game information contained in the advertisement, acquires a new, often unexpected sound. Language game allows you to realize the fundamental principle of creating a vivid advertising message: at the minimum of the text the maximum expression, which can best be traced on examples not only relevant advertising texts, but also advertising slogans and commercial names, brands of certain companies. On the other hand, when using the phenomena of the linguistic game, there is a problem of observance of linguistic and other norms, the solution of which will enable to neutralize the negative influence of some types of advertising, which is extremely necessary in the conditions of the unstable social and economic situation in Ukraine, modern trends of 4.0 Industry and development of some other countries and is real in conditions of using specific scientific methods for comparing different input parameteres, for example, desing of experiments [27-29].

\section{Acknowledgements}

The authors would like to thank Oleg Balatskyi Academic and Research Institute of Finance, Economics and Management of Sumy State University and particurly the Department of Marketing and MIA for their support. The authors would like to acknowledge the Sumy State Pedagogical University named after Makarenko for their invaluable support provided throughout the current study. 


\section{References}

[1] Y. Hole, S. Pawar and M.P Bhaskar "Service marketing and quality strategies". Periodicals of Engineering and Natural Sciences, vol. 6(1), pp. 182-196, 2018.

[2] A.S. Teletov, "Advertising management", $3^{\text {th }}$ edition, Universytetska knyga, 2015.

[3] D. D'Alessandro and M. Owens, "Brand Warfare: 10 Rules for Building the Killer Brand", McGraw Hill Professional, 2002.

[4] J.R. Gregory, "Leveraging the Corporate Brand". Lincolnwood, Ill., NTC Business Books, 1997.

[5] Dzh. Traut, "New positioning", Piter, 2001.

[6] U. Arens, M.F.Vejgold and K. Arens, "Modern advertising", Eksmo, 2010.

[7] S. Sallivan and S. Bennet, "Anatomy of advertisements. How to create selling texts", Piter, 2016.

[8] Ye.V. Romat, "Advertising in the marketing system", NVF "Studtsentr", 2008.

[9] T.K. Bhatia and W.C Ritchie., "The Bilingual Mind and Linguistic Creativity". Journal of Creative Communications, vol. 3(1), pp. 5-21, 2008.

[10] T.K. Bhatia and W.C. Ritchie, "Bilingualism and Multilingualism in the Global Media and advertising. The Handbook of Bilingualism and Multilingualism", 2013.

[11] I.V. Ivanova, "Discourse, text, style: a model of linguistic research of advertising". Scientific notes of the Berdyansk State Pedagogical University, vol. 5, pp. 4-38, 2015.

[12] M.V. Laskova and Yu.V. Popova, "Linguocultural features of the language game in the advertising picture of the world", IPO YuFU, 2013.

[13] N.N. Kohtev, "Advertising: the art of words. Advice for copywriters", Izd-vo MSU, 2004.

[14] I.G. Morozova, "Composing slogans", RIP-Holding, 2007.

[15] L.P. Amiri, "Graphic occasional character as a means of style in the texts of advertising discourse (on the material of the XX-XXI centuries)". Proceedings of the PGPU named after V.G. Belinsky (humanities), 2012, pp. 176-182.

[16] Vysotskaia, I.V., (2010). "“His" and "alien", or the interaction of Cyrillic and Latin in modern advertising text . Bulletin of Nizhny Novgorod University named after N.I. Lobachevsky (Linguistics), vol. 4(2), pp. 471-474, 2010.

[17] S.V. Iliasova and L.P. Amiri, "Language of the media and advertising: the game as the norm and as an anomaly", Flinta, 2016.

[18] B.Yu. Norman, "The game on the edges of the language", LitRes, 2017.

[19] Vitgenshtein, L. "Man and thinker", Progress, 1993.

[20] O.S. Ahmanova, "Linguistic vocabulary", $4^{\text {th }}$ edition, Ripol Klassik, 2013.

[21] T.V., Matveeva, "Complete dictionary of linguistic terms", Feniks, 2010.

[22] E.S. Kara-Murza, "Teaching and studying Russian commercial advertising in Media University". Medialinguistics, vol. 5(1), pp. 97-109, 2018.

[23] A.S. Teletov and S.G. Teletova, (2018). Verbal means of indirect commercialization of innovative products of enterprises. Development of the mechanism of commercialization of innovative products. Illiashenko S.M., Bilovodska O.A. (Eds), Trytoriya, 2018.

[24] A.S. Teletov and Teletova S.G., "Ecological slogans in the system of environmental protection. International economic relations and sustainable development". Prokopenko O., Kurbatova T. (Eds.). Drukarnia i Studio Graficzne Omnidium, 264-271, 2017.

[25] S. Godin, "Purple cow. Make your business outstanding", $5^{\text {th }}$ edition, Mann, Ivanov i Ferber, 2014.

[26] F. Kotler, "Marketing in the third millennium: how to create, conquer and keep the market", AST, 2000.

[27] V,. Babenko, "Formalization of the Model of Management of the Technological Innovations", Proc. 15th Int. Conf. on ICT in Education, Research and Industrial Applications. Integration, Harmonization and Knowledge Transfer (ICTERI2019). Volume II: Workshops, Ed. by Ermolayev, V., Mallet, F., Yakovyna, and oth. (Eds.), Kherson, Ukraine, June 12-15, 2019. Pp. 595-602. CEUR-WS.org, Vol. 2393, online, http://ceur-ws.org/Vol-2393/, 2019. URL: http://ceur-ws.org/Vol-2393/paper_431.pdf

[28] C. Barz, K. Jalba Claudius, Z. Erdei and L. Hahn Sarah Myriam, "Approaches for the planning and implementation of Industry 4.0”, Periodicals of Engineering and Natural Sciences, vol. 7(1), pp. 375-380, 2019.

[29] B. Durakovic, "Desing of experiments application, concepts, examples: state of the art", Periodicals of Engineering and Natural Sciences, vol. 5(3), pp. 421-439, 2017. 